Slađana Mladenović, ${ }^{*}$

Research Associate,

Institute for Political Studies, Belgrade
ПРЕГЛЕДНИ НАУЧНИ РАД

10.5937/zrpfn0-31769

UDK: 340.134:619](4-672EU)

338.439

Рад примљен: 09.04.2021.

Рад прихваћен: 24.05.2021.

\title{
THE ROLE OF THE EUROPEAN FOOD SAFETY AUTHORITY IN THE ACTIVE SUBSTANCE APPROVAL AND RENEWAL PROCEDURES WITHIN THE EU PESTICIDE POLICY ${ }^{* *}$
}

\begin{abstract}
The EU decentralised agencies are involved in various sectorial EU policies and related composite procedures. One of the agencies, the European Food Safety Authority (EFSA), has a prominent role in the composite procedures within the EU pesticide policy - the active substance approval and renewal procedures. These procedures represent the initial steps in the complex administrative process of placing on the market and control of use of plant protection products. The procedures are arranged under the linear risk analysis model within which the scientific risk assessment is performed by Member States and the EFSA, while the political risk management is performed by the Commission and Member States in the comitology procedure. After a brief analysis of the key stages and outcomes of the procedures, the paper discusses two topics. The first relates to the properties of three key aspects of the EFSA's role in the procedures: 1) involvement in adopting guidance documents; 2) publishing appropriate documents and deciding on confidentiality requests; and 3) preparing and submitting the conclusion, its main scientific output related to active substance. The second topic includes five elements of confidence in the EFSA regarding the course and outcome of the procedure: efficiency, independence, transparency, high scientific quality and effective risk communication. The paper discusses the properties of the elements, the main identified challenges associated with them, as well as ongoing and future responses to these challenges, especially those introduced by the Transparency Regulation, adopted in 2019 and applicable from 27 March 2021.
\end{abstract}

\footnotetext{
*sladjana.mladenovic@ips.ac.rs

${ }^{* *}$ The paper has been developed within the research activities of the Institute for Political Studies, Belgrade, supported by the Ministry of education, science and technological development of the Republic of Serbia.
} 
Keywords: EU decentralised agencies, European Food Safety Authority, EU pesticide policy, active substance approval, active substance renewal, General Food Law, Plant Protection Products Regulation, Transparency Regulation.

\section{Introduction}

The EU pesticide policy (EUPP) refers to placing on the market and control of use of plant protection products (PPPs). In order to be placed on the market and used, a PPP has to be authorised by a Member State (MS). Prior to the PPP authorisation, an active substance (AS) - a chemical, a micro-organism or a pheromone which enables a PPP to perform its function, has to be approved at the EU level. The European Food Safety Authority (EFSA), a decentralised EU agency, has a prominent role in that process.

The ASs used in PPPs were originally covered by the legislation on hazardous chemicals with the primary goal of removing trade barriers within the Community. Therefore, despite some uniform rules, there was no restriction on the use of those ASs (Vogel, 2012: 154). The subsequent legislation established the pre-approval safety requirements and imposed bans and restrictions on certain ASs at the Community level (Christoforou, 2004: 19). By adopting the Directive 91/414 (PPPD) ${ }^{1}$ which harmonised the placing of PPPs on the market, the AS approval and renewal procedures were established at the Community level. Originally, the procedures involved only the Commission and MSs, and the EFSA got involved in 2003.

The legal framework governing the current AS approval/renewal system and the EFSA's role in it includes:

1) Regulation $178 / 2002$ (GFL) which established the EFSA; ${ }^{2}$

2) Regulation 1107/2009 (PPPR), which repealed the PPPD, arranged the procedures and defined the processes and substantive approval/renewal criteria; ${ }^{3}$

1 Council Directive 91/414/EEC of 15 July 1991 concerning the placing of plant protection products on the market, OJ L 230, 19.8.1991, p. 1-32.

2 Regulation (EC) No 178/2002 of the European Parliament and of the Council of 28 January 2002 laying down the general principles and requirements of food law, establishing the European Food Safety Authority and laying down procedures in matters of food safety, OJ L 31, 1.2.2002, p. 1-24 (hereinafter: GFL 2002).

3 Regulation (EC) No 1107/2009 of the European Parliament and of the Council of 21 October 2009 concerning the placing of plant protection products on the market and repealing Council Directives 79/117/EEC and 91/414/EEC, OJ L 309, 24.11.2009, p. 1-50 (hereinafter: PPPR 2009). 
3) Commission Implementing Regulation 844/2012, which arranged the renewal procedure in detail; ${ }^{4}$ and

4) Commission Regulation $283 / 2013$ setting out the data requirements for ASs. ${ }^{5}$

The system was rearranged in 2019 in response to the European Citizens' Initiative on glyphosate and the findings of the GFL evaluation (Chatzopoulou, Leiva Eriksson, Eriksson, 2020: 354). Changes were introduced by: 1) the Transparency Regulation 2019/1381 (TR) that amended both GFL and PPPR; ${ }^{6}$ and 2) the new Commission Implementing Regulation 2020/1740 on the renewal procedure. ${ }^{7}$ Both are applicable from 27 March $2021 .^{8}$

The importance of the EFSA's role in the AS approval/renewal procedures should be evaluated against the EUPP's financial backdrop and strategic goals. Around the time the EFSA got involved, the EU PPP market had generated revenue of approximately $€ 7$ billion, while the costs of developing a new AS and PPP had been approximately €190 million. By 2016, the numbers increased to $€ 12$ billion and €250 million, respectively (European Commission [EC], 2020a: 11-12, 18). In addition, the producers spend approximately $€ 300$ million annually on preparing dossiers for approval/renewal procedures (EC, 2020a: 64).

The main EUPP strategic goals include reducing dependence on chemical PPPs, especially if they contain high-risk chemical ASs, and increasing the use of PPPs based on low-risk ASs, especially micro-organisms and pheromones. The goals were introduced in the strategic document on sustainable use of PPPs (Commi-

4 Commission Implementing Regulation (EU) No 844/2012 of 18 September 2012 setting out the provisions necessary for the implementation of the renewal procedure for active substances, as provided for in Regulation (EC) No 1107/2009 of the European Parliament and of the Council concerning the placing of plant protection products on the market, OJ L 252, 19.9.2012, p. 26-32 (hereinafter: Renewal 2012).

5 Commission Regulation (EU) No 283/2013 of 1 March 2013 setting out the data requirements for active substances, in accordance with Regulation (EC) No 1107/2009 of the European Parliament and of the Council concerning the placing of plant protection products on the market, OJ L 93, 3.4.2013, p. 1-84.

6 Regulation (EU) 2019/1381 of the European Parliament and of the Council of 20 June 2019 on the transparency and sustainability of the EU risk assessment in the food chain and amending Regulations (EC) No 178/2002, (EC) No 1829/2003, (EC) No 1831/2003, (EC) No 2065/2003, (EC) No 1935/2004, (EC) No 1331/2008, (EC) No 1107/2009, (EU) 2015/2283 and Directive 2001/18/EC, PE/41/2019/REV/1, OJ L 231, 6.9.2019, p. 1-28 (hereinafter: TR 2019).

7 Commission Implementing Regulation (EU) 2020/1740 of 20 November 2020 setting out the provisions necessary for the implementation of the renewal procedure for active substances, as provided for in Regulation (EC) No 1107/2009 of the European Parliament and of the Council, and repealing Commission Implementing Regulation (EU) No 844/2012, C/2020/7982, OJ L 392, 23.11.2020, p. 20-31 (hereinafter: Renewal 2020).

8 Art. 11, TR 2019; Art. 18, Renewal 2020. 
ssion of the European Communities, 2006: 11), built into the PPPR and reaffirmed in the newest strategies, such as the European Green Deal (EC, 2019a: 12) and the Farm to Fork Strategy (EC, 2020b: 3, 6). The results achieved so far include: 1) the significant decrease of total number of ASs on the market (EC, 2020a: 8, $18) ; 2)$ the low share of high-risk ASs and relatively large (37\%) and increasing proportion of ASs of less problematic profiles (EC, 2020c: 4); and 3) about 40\% of new applications for ASs concern micro-organisms or presumably low-risk ASs (EC, 2020a: 28). The main future objectives include reducing the overall use of chemical PPPs by $50 \%$ by 2030 and additional incentives in developing and using PPPs based on low-risk and microbial ASs (EC, 2020b:6).

\section{Approval and renewal procedures}

The AS approval and renewal procedures are arranged under the linear risk analysis model characterised by the strict procedural separation of the scientific risk assessment performed by MSs and the EFSA, and the political risk management performed by the Commission and MSs in the comitology procedure (Bozzini, 2017: 29; Morvillo, 2020: 425). The approval/renewal procedure is a form of composite procedure i.e. multiple-step procedure with input from administrative actors both from the MSs and the EU (Hofmann, 2009: 136). The stages of the procedures are basically the same, with certain peculiarities of the renewal procedure.

The approval procedure begins when the AS producer submits the application and necessary dossiers to the MS of his choice. The MS, which becomes the Rapporteur Member State (RMS), conducts the assessment on its own or jointly with another MS under a co-rapporteur system..$^{9}$ After the assessment of the formal admissibility criteria of the application and the dossiers, the RMS carries out the risk assessment of the AS. The outcome of the risk assessment is the Draft Assessment Report (DAR), which answers the question whether it can be expected for the AS to comply with the approval criteria. ${ }^{10}$ The renewal procedure has two peculiarities in this stage. First, the RMS and co-RMS (or a group of MSs acting as a RMS) for each AS are predetermined by the Commission. ${ }^{11}$ Second, there is a two-step approach in the assessment of the formal admissibility criteria: the application is assessed first and the dossier later on. The application should be submitted three years prior to the end of the approval period at the latest. ${ }^{12}$ If the application and the dossier are acceptable, the

9 Art. 7(1), (2), 8(1)-(3), 79(2), PPPR 2009.

10 Art. 4, 9-11, PPPR 2009.

11 Art. 1(1), (3), Renewal 2012.

12 Art. 15(1), PPPR 2009; Art. 1(1), (3), 2(2), 3, 6-8, Renewal 2012. 
RMS begins to assess the fulfillment of the substantive criteria in accordance with the approval model. The final outcome is the draft Renewal Assessment Report (RAR).$^{13}$ Upon sending the DAR/RAR to the Commission and EFSA, the risk assessment within the EFSA begins.

The EFSA stage of the approval procedure has three phases of the so-called peer-review of the pesticide risk assessment (Rimkute, 2018: IV-59). First, the EFSA publishes the DAR. ${ }^{14}$ Second, the DAR is being commented by the applicant, other MSs and the public. ${ }^{15}$ In the final phase, the EFSA submits its scientific outcome, which is in the form of a conclusion. During the process of preparing the conclusion, the EFSA may organise a consultation of experts, including experts from the RMS, and request additional information from the applicant. The EFSA's conclusion is submitted to the applicant, all MSs and the Commission, and eventually published..$^{16}$ The conclusion includes the details of the assessment procedure and the properties of the AS..$^{17}$ In the renewal procedure, the first two phases are mandatory, mirroring the approval procedure. ${ }^{18}$ However, the EFSA's conclusion is not always mandatory; after the commenting phase, the Commission decides whether it is necessary. ${ }^{19}$

After the risk assessment stage is finished, the risk management stage begins. Its final outcome is the decision on the approval or renewal of approval of AS, adopted in the form of the Commission Implementing Regulation. ${ }^{20}$

Each stage of the procedure has precisely defined deadlines which can be extended if consultation or additional information from the applicant is needed (in the so-called stop-the-clock procedure). Ideally, the decision on AS approval should be taken in the period of two years and two and a half months, or in three years and five and a half months if stop-the-clock procedure is used (Bozzini, 2018: II-69). The renewal procedure has to end within three years since the submission of the application.

13 Art. 11, Renewal 2012.

14 Art. 12(1), 63, PPPR 2009.

15 Art. 12(1), PPPR 2009.

16 Art. 12(2), (3), PPPR 2009.

17 Art. 12(4), (5), PPPR 2009.

18 Art. 12, Renewal 2012.

19 Art. 13(1), Renewal 2012.

20 Art. 13(1), (2), 20(1), 79(1), (3), PPPR 2009; Art. 14, Renewal 2012. 


\section{Key aspects of the EFSA's role in AS approval and renewal procedures}

There are three key aspects of the EFSA's role in AS approval/renewal procedures. First, the EFSA participates in the design of the procedure by adopting guidance documents. The remaining two aspects are related to the course and outcome of the procedure; they include: 1) deciding on requests for confidentiality and publication of documents; and 2) preparing and submitting the conclusion.

\subsection{Guidance documents}

Guidance documents serve as a translation of the legal requirements into practical steps. They can be: 1) technical, related to AS data requirements; and 2) procedural, providing further clarifications on the procedure (Nganga, Bisonni, Christodoulou, 2018: 16, 26). The development and update of guidance documents led to the harmonisation of the AS assessment criteria, which is particularly important during the risk assessment at the RMS stage. The EFSA's prominent role in this process is acknowledged by the MSs (Bozzini, 2018: II-93).

There are four grounds of the EFSA's participation in the adoption of guidance documents. First, at the request of the Commission, the European Parliament (EP) or a MS, or on its own initiative, the EFSA may adopt a scientific opinion on matters within its mission..$^{21}$ The EFSA has already used this competence to adopt technical guidance on its own initiative (European Food Safety Authority [EFSA], 2015: 11). Second, the Commission may ask for the EFSA's scientific or technical help in any area within the EFSA's mission, particularly in developing technical guidance. ${ }^{22}$ Third, the Commission may ask the EFSA to prepare or contribute to the guidance documents on the applications concerning microorganisms and pheromones. ${ }^{23}$ Finally, the EFSA defines the criteria of relevance and reliability of the scientific peer-reviewed open literature on the AS which the applicant must submit as an addition to the AS dossier. ${ }^{24}$ The EFSA has defined those criteria in its technical guidance (EFSA, 2011).

Guidance documents used in the approval/renewal procedures can be classified into two groups. The first group consists of the guidance documents listed in the Commission Communication (EC, 2013) which complemented the Implementing Regulation on data requirements. They are not legally binding per se, although in practice they operate as mandatory (Nganga et al. 2018: 32). The second gro-

21 Art. 29(1)(a), (b), GFL 2002.

22 Art. 31(1), GFL 2002.

23 Art. 77, 79(2), PPPR 2009.

24 Art. 8(5), PPPR 2009. 
up consists of three types of guidance documents outside the Communication. The first type are technical guidance documents listed on the Commission DG SANTE's website, adopted by the DG or the EFSA. In the latter case, they must be noted by the Commission (Nganga et al. 2018: 32-34). The second type are the procedural guidance documents listed on the DG SANTE's website, mostly developed by the DG (Nganga et al. 2018: 32-34). The third type are the EFSA's non-noted technical guidance documents, scientific opinions and technical reports, listed on the EFSA's website (Nganga et al. 2018: 35-37). The guidance documents outside the Communication are not legally binding per se although, in practice, the EFSA-authored guidance documents noted by the Commission are de facto mandatory (Nganga et al. 2018: 42).

The key stakeholders from the academia, non-governmental organisations (NGOs) and industry have identified certain challenges concerning the adoption, quality and application of the guidance documents.

The issue of adoption varies across different areas. The guidance documents on chemical ASs in some areas are consolidated and up to date with the latest scientific developments, while in others the criteria and methodology are less consolidated (Bozzini, 2018: II-93-94). The guidance documents on low-risk chemical ASs have been developed and are in the process of adoption, while the ones on the microbial ASs are still in the developing phase (EC, 2020a: 92).

The quality of the guidance documents is being questioned. The scholars and NGOs consider that they are not always in line with the latest scientific developments (Robinson, Portier, Čavoški, Mesnage, Roger, Clausing, Whaley, Muilerman, Lyssimachou, 2020: 452) and certain data gaps have been identified (Bozzini, 2018: II-33). Also, NGOs point out that the content of the guidance documents is influenced by the industry (Robinson et al. 2020: 477). For its part, the industry complains that the guidance documents are "demanding, expensive, and not proportionate to the risk to be evaluated" and that their frequent update leads to the changes in the already prepared dossiers or the provision of additional information, significantly slowing down the procedure (Bozzini, 2018: II-33).

Most stakeholders criticise the application of the guidance documents due to the existence of certain regulatory insecurity during the risk assessment; the RMSs selectively apply the non-noted EFSA-authored guidance documents which, however, the EFSA may use (Bozzini, 2018: II-33; Nganga et al. 2018: 35). 


\subsection{Confidentiality decisions and publication of documents}

The requirement for transparency of the risk assessment ${ }^{25} \mathrm{implies}$ that all documents in the procedure are publicly available. The EFSA publishes the application, summary dossiers, the DAR/RAR and its conclusion, except for those parts on which confidentiality was granted upon the applicant's request. The RMS decides on the confidentiality requests regarding the application and dossiers, while the EFSA decides on the confidentiality of the remaining documents. ${ }^{26}$ Identified challenges and stakeholder criticism regarding confidentiality decisions shall be expounded later, in the section on Transparency.

\subsection{Preparing and submitting the conclusion}

The conclusion is the main scientific output of the EFSA. Its purpose is twofold. On the one hand, the conclusion represents the basis for "sound decision making" of risk managers (Hardy, Fontier, 2011: 1-2). The EFSA external evaluations have affirmed that its scientific outputs have been used in the EU risk management (EC, 2018b: 69), except in few cases in which the Commission's decision was not in line with them (EC, 2018a: 37). On the other hand, preparation of the conclusion is the key factor in promoting consistency of the procedure, favouring the application of harmonised guidance documents and facilitating a learning process among MSs, which can regularly discuss scientific and methodological issues. According to the EFSA, all DARs and RARs are significantly revised after the commenting phase (Bozzini, 2018: II-84, II-86, II-96).

In the view of MSs, there are two key shortcomings of the EFSA's conclusion. First, the conclusion is often regarded as "inconclusive". Although the EFSA highlights the remaining data gaps and areas of concern, it leaves the decision on the relevance of identified problems and their policy implications to the risk managers (Bozzini, 2017: 48). Second, some MSs criticise the EFSA for not taking into account their comments properly (Bozzini, 2018: II-86). The EFSA and MSs have jointly defined key measures in order to eliminate these shortcomings; the EFSA's conclusion shall: 1) include the divergent scientific views of MSs in the commenting phase; and 2) address the uncertainties, including contradictory evidence or lacking data by demonstrating different outcomes/endpoints associated with them (EFSA, 2017a: 7).

25 Art. 11(2), PPPR 2009; Art. 11(3), Renewal 2012.

26 Art. 10, 12(1), (2), 16, 63, PPPR 2009; Art. 5, 8(4), 12(4) 13(2), Renewal 2012. 


\section{Confidence in the EFSA regarding the course and outcome of the procedure}

The lack of regulatory powers of the EFSA makes the confidence in its outputs the focal point of its activity (Abels, Kobusch, Träsch, 2016: 76-77). GFL proclaims the confidence of the EU institutions, the general public and interested parties in the EFSA as a key value which is to be attained by ensuring the EFSA's efficiency, independence, transparency, high scientific quality and effective risk communication. ${ }^{27}$ While efficiency is related to meeting defined deadlines for the outputs, the remaining four elements are related to process reliability and output quality. Despite the prevailing high level of confidence in the EFSA by MSs and the Commission (Ludden, Godfrey, Kobilsky, Hahn, Jansen, 2018: 121), the challenges with all five elements have been identified in the approval/renewal procedures. Some of them are generated by the system setup and the limited capacity of MSs and the EFSA for its application, while others stem from the conflicting interests of the key stakeholders: the environmental NGOs and the industry. These challenges have been manifested to the greatest extent during the renewal procedure of glyphosate, one of the most commonly used ASs in PPPs at the EU market.

\subsection{Efficiency}

Despite the general appraisal of the EFSA as efficient (Ludden et al. 2018: 121), there have been significant delays in approval/renewal procedures. The approval procedure takes on average several months longer than prescribed, and for certain ASs a year or two longer (EC, 2020a: 69). The delays in renewal procedures have been mainly observed regarding the ASs approved before 2009. The delays in the renewals led to the prolongation of final decisions on ASs well beyond the legal deadline (Bozzini, 2017: 107), and by October 2018 no AS has been renewed within the initial approval period (EC, 2020a: 69).

The delays in the renewals have led the Commission to extend approval periods to allow for the completion of the procedures, which was heavily criticised by the EP and NGOs (EC, 2020a: 69). Significant delays and extensions of approval periods also delay the placing of low-risk ASs on the market and keep on the market the ASs that can later be found not to fulfill the approval criteria anymore (EC, 2020c: 4), contrary to the EUPP strategic goals.

The main reasons for the delays are systemic in nature, three of which stand out. First, there are reasons stemming from the nature of the procedure, mostly related to the increasingly complex data requirements and the need to evaluate

27 Rec. 35, 40, Art. 22(7), GFL 2002. 
a large number of dossiers simultaneously (Bozzini, 2018: II-80). Second, due to huge differences among MSs in terms of available expertise, many of them lack the capacity to act as a RMS (Bozzini, 2018: II-80-81). Finally, the EFSA's capacity to plan its work is reduced due to: 1) the increase in the number of sectorial legislation obliging the EFSA to conduct risk assessment (EC, 2018a; 29-31); and 2) budgetary constraints in increasing staff in the period 2014-2020 (EFSA, 2020: 53).

One specific reason for the delays concerns the lack of early dialogue with the applicants. The EFSA and the RMS have the obligation to cooperate with the applicants during the procedure in order to resolve any questions or identify the need for further explanations or additional studies. ${ }^{28}$ However, such obligation does not exist prior to the submission of the application. Therefore, the applicants face difficulties in preparing the necessary dossiers and adapting them to the new legislation, which later causes the frequent use of stop-the-clock procedures and delays (Bozzini, 2018: II-87; EC, 2018a: 32).

The problem of delays is solved in four directions, namely by: 1) simplifying the procedure and facilitating communication; 2 ) advancing the dialogue between the participants in the procedure; 3 ) establishing early dialogue with the applicants; and 4) increasing the EFSA's financial and human resources.

The simplification of the procedure and facilitating communication take place on two levels. On a general level, the EFSA is obliged to establish and manage an online central submission system for submission of applications and information exchange between the participants in the procedure. ${ }^{29}$ On a special level, the two-step approach in the renewal procedure is abandoned. The application and the dossiers shall be submitted simultaneously, thus reducing the time necessary for the assessment of the formal admissibility criteria. ${ }^{30}$

The advancement of the dialogue is achieved in three ways. First, the EFSA prepared the document with questions and answers on the procedure for MSs (EFSA, 2017a: 5). Second, e-consultation groups are envisioned in order to facilitate the exchange of information, expertise and experience between the experts in MSs and the EFSA (EFSA, 2017a: 5). Finally, an ad-hoc working group on accordance check is established, consisting of the EFSA, the European Chemicals Agency and the MSs. In relation to both the summary dossier and the DAR/RAR, the working group: 1) performs the accordance check; and 2) aims to develop EU-wide criteria for the advancement of their quality (EFSA, 2017a: 6). On the basis of its work,

28 Annex II, point 1.1, PPPR 2009.

29 Art. 39f, GFL 2002, as amended by Art. 1(9), TR 2019; Art. 5(1), 7(1), (2), Renewal 2020. 30 Art. 32b(4), (5), GFL 2002, as amended by Art. 1(6), TR 2019; Art. 6(1), (2), 8(1)(b), (c), Renewal 2020. 
in 2019 the EFSA adopted the administrative guidance on submitting dossiers and assessment reports (EFSA 2019a) that was mandatory (EC, 2019b: 2-3). The recently adopted new guidance (EFSA, 2021a) is also mandatory (EC, 2021: 3).

In terms of early dialogue, the EFSA made a commitment to provide advice to the applicant prior to the application submission (EFSA, 2019b: 6). Upon the adoption of the TR, the EFSA is formally obliged to: 1) provide the pre-submission advice on the rules or the content of the application or notification to potential applicants or notifiers; and 2) publish general guidance on rules applicable to applications or notifications. ${ }^{31}$

In terms of increasing resources, the EFSA had asked for additional staff due to higher workload, but they became available only at the end of 2016 (EFSA, 2020: 53). The multiannual budget in the period 2021-2027 envisioned additional resources and staff in 2021 and 2022. However, the EFSA considers this insufficient given the workload and new tasks emanating from the TR implementation (EFSA, 2020: 55).

\subsection{Independence}

The EFSA's independence is ensured by a complex EU-wide system for the prevention of the conflict of interests (CoI), established by secondary and soft law provisions (Vos, Athanasiadou, Dohmen, 2020). The EFSA's independence policy was comprehensively evaluated for the first time in 2012. It showed that the EFSA has one of the most advanced and robust systems for providing independence (EC, 2018b: 73; European Court of Auditors [ECA], 2012: 37), especially concerning the industry-related risks (ECA, 2012: 20). The shortcomings identified in defining and implementing the assessment criteria of the CoI (ECA, 2012: 18, $24,26,31,38)$ and the post-employment policy regarding the EFSA's employees (ECA, 2012: 35) have been addressed following the adoption of the new internal rules on independence (EFSA, 2014b; EFSA, 2017c; EFSA, 2018). The latest external evaluation concluded that the EFSA has "robust measures in place to ensure independence" (Ludden et al. 2018: 63). However, many stakeholders, especially NGOs, consider the EFSA's independence controversial and accuse the EFSA of having too close ties with the industry as well as of serious misconducts regarding the CoI (Rimkutè, 2018: IV-50-51; Robinson et al. 2020: 475-477).

Due to the increasingly restrictive CoI policy over the years, the EFSA has faced difficulties in recruiting high-level experts, a problem faced by all EU agencies (Ossege, 2015: 109). The EFSA observed this issue in 2012, when it was recognised that certain CoI situations are inevitable but need not imply misconduct or

31 Art. 32a, GFL 2002, as amended by Art. 1(6), TR 2019; Art. 4, Renewal 2020. 
corruption, especially in highly specialised or unique organisations in which it is difficult to obtain expertise because the industry "competes" for the same experts as agencies (ECA, 2012: 11). Therefore, EU agencies experience continuous struggle to balance the need for expert knowledge and the threat on their independence (Ossege, 2015: 110). While NGOs, supported by some EP members and MSs, believe that any tie with the industry, including public-private partnerships that finance the areas in which experts are engaged, should be considered as a CoI (EC, 2018b: 75), other MSs believe that additional tightening of the rules on independence would increase the risk of losing expertise (EC, 2018b: 40, 88).

\subsection{Transparency}

The majority of stakeholders perceive the EFSA as a transparent organisation (EC, 2018b: 84). However, some of them, mostly NGOs and the EP, challenge its transparency due to insufficient availability of industry studies. The main challenges concern: 1) the decisions on confidentiality; and 2) the possibility for the applicants to leave out the unfavourable studies.

The AS risk assessment is performed based on studies submitted by the applicant, i.e. industry, since the burden of proof in on the applicant (Morvillo, 2020: 427). However, the industry-originated studies raise concerns about the appropriate balance between the public interest in access to information and the private interest in confidentiality of the commercially sensitive information (Morvillo, 2020: 428). NGOs think that the EU applicable legislation excessively restricts the access to the industry studies (EC, 2018b: 84). The glyphosate renewal procedure was generally deemed to be non-transparent (Röttger-Wirtz, 2020b: 31-32); due to great public distrust, there has been a number of requests for access to documents and some actions before the Court. In the Court's interpretation, the increased transparency was connected with the constitutional values of democracy, accountability and participatory openness which ultimately led to the adoption of the TR (Röttger-Wirtz, 2020b: 26).

The TR brings three key novelties for advancing transparency. First, the EFSA's powers in deciding on confidentiality are extended in two ways: 1) during the approval procedure, the RMS has the obligation to consult the EFSA when deciding; and 2) in the renewal procedure, the EFSA shall assess all requests in all stages. ${ }^{32}$ Second, a detailed procedure for confidentiality requests and decisions thereon is provided. ${ }^{33}$ The EFSA was tasked with adopting practi-

32 Art. 7(3) PPPR 2009, as amended by Art. 7(1)(b), TR 2019; Art. 16 PPPR, as amended by Art. 7(4), TR 2019; Art. 63(1)-(2a), PPPR 2009, as amended by Art. 7(5), TR 2019; Art. 6(7), 11(5), Renewal 2020.

33 Art. 39a-39d, GFL 2002, as amended by Art. 1(9), TR 2019. 
cal arrangements, ${ }^{34}$ which were adopted in January 2021 (EFSA, 2021b; EFSA, 2021c). Finally, a system of appeals against decisions regarding confidentiality requests is gradually being introduced. The first phase involves a confirmatory application with a suspensive effect as a form of interlocutory revision of the EFSA's decisions. ${ }^{35}$ The subsequent phase would be the establishment of a Board of Appeal to deal with the decisions on requests for confidentiality and confirmatory applications. It shall be considered within the evaluation of the EFSA to be performed by the Commission by the end of March 2026. ${ }^{36}$

The possibility of excluding the unfavourable studies by the applicants was the second challenge to the EFSA's transparency. The requirements of the PPPR did not provide any safeguard against such possibility (Morvillo, 2020: 428), i.e. the applicants could have stopped or not submit the studies that would provide evidence for risk to human health or the environment (Röttger-Wirtz, 2020a: 541).

The provisions of the TR revoke this possibility by introducing the notification to the EFSA of all studies intended to be carried out in support of an application prior to its submission. A prior notification is the obligation of both the applicants and the laboratories. ${ }^{37}$ In the renewal procedure, the prior notification shall be followed by stakeholder and public consultations on the studies, including on their design. On the basis of consultations, the EFSA shall provide advice on the content of the application or notification and on the design of studies. After the submission of the application and the dossier and their publication, the EFSA shall organise another round of consultations in order to identify other relevant scientific data or studies. ${ }^{38}$ The EFSA adopted practical arrangements in this regard in January 2021 (EFSA, 2021d).

\subsection{High scientific quality}

High scientific quality refers to the quality of the EFSA's scientific outputs and the reliability of the process of their development. The EFSA's scientific outputs are generally accepted in the mainstream scientific community and among MSs' authorities (EC, 2018a: 33) and considered to be reliable (EC, 2018b: 39-40, 68). However, there is a widespread concern in EU public opinion regarding the objectivity of scientific outputs, which applies to EFSA as well (Smith, Terry, Detken, 2012: 114). The experts' competence and the final outcome are conte-

34 Art. 7(3) PPPR 2009, as amended by Art. 7(1)(b), TR 2019; Art. 16 PPPR, as amended by Art. 7(4), TR 2019.

35 Art. 39b(1)(d), (2), GFL 2002, as amended by Art. 1(9), TR 2019.

36 Art. 61(3), GFL 2002, as amended by Art. 1(12), TR 2019.

37 Art. 32b, GFL 2002, as amended by Art. 1(6), TR 2019.

38 Art. 32c, GFL 2002, as amended by Art. 1(6), TR 2019; Art. 3, Renewal 2020. 
sted on different grounds. The industry points to the EFSA's informal ties with the environmental lobbies, while the NGOs underscore the ties with chemical lobbies (Bozzini, 2017: 47).

The foremost examples of contestation include the procedures regarding neonicotinoids and glyphosate. In the former, the EFSA's scientific output led to the ban of neonicotinoids as harmful. It was an adverse outcome for the industry which criticised the procedure for having favoured the laboratory studies (which more often point to the hazardousness of the substance) over the field research and for having performed the assessment under a political pressure by the public and many environmental NGOs (Rimkute, 2015: 122-125). In the glyphosate renewal procedure, on the basis of the EFSA's scientific output, a decision was made to renew the approval of the AS considered as carcinogenic by a part of the general public and scientific community. The problem arose due to the conflicting outputs of two scientific bodies which assessed glyphosate independently of one another: the International Agency for Research on Cancer (IARC) which concluded that glyphosate is probably carcinogenic, and the EFSA which concluded that glyphosate is unlikely to pose any carcinogenic risk to humans (Rimkutè, 2018: IV-16, IV-22-23). Challenging the EFSA's methodology and the correctness of its Weight of Evidence approach, critics from that part of the scientific community, NGOs and certain EP members pointed out that the glyphosate risk assessment was conducted primarily on the basis of the industry-originated studies favouring glyphosate while neglecting numerous independent peer-reviewed studies pointing to its carcinogenicity (Robinson et al., 2020: 454-463). On the other hand, the EFSA's experts involved in the procedure argued that high scientific standards were applied during the procedure, and that the different scientific outcomes were the result of specific differences in mandates, legal frameworks, procedures and epistemological approaches between these two bodies (Rimkutè, 2018: IV-91-96; Paskalev, 2020: 521-523; Röttger-Wirtz, 2020b: 14-15).

Bearing in mind that the contestation of the EFSA's objectivity was based on the conflicting findings of different scientific studies, the TR provided a solution for overcoming such situations. In cases of serious controversies or conflicting results, the Commission may request the EFSA to commission scientific studies in order to verify evidence used in the risk assessment process. ${ }^{39}$ Although this solution has the potential to mitigate the prevalence of industry-originated studies (Morvillo, 2020: 431-432), thus removing a number of reasons for contesting the EFSA's objectivity, the critics argue that the only way to achieve this is to give the EFSA a mandate to commission all tests instead of the industry, which should not have the opportunity to choose a laboratory, design or

39 Art. 32d, GFL 2002, as amended by Art. 1(6), TR 2019. 
conduct of the studies (Robinson et al. 2020: 473). In theory, it would diminish the influence of the industry on the assessment procedure but, in practice, the burden of proof would be transferred from industry to the EFSA, which would have to commission the studies in the same laboratories which perform most of the tests for the current industry studies (EC, 2018a: 34-35).

\subsection{Risk communication}

Risk communication refers to interactive exchange of information and opinions among stakeholders throughout the risk analysis process on risk-related issues, risk assessment findings, and the basis of risk management decisions. ${ }^{40}$ It is shared between the EFSA, the Commission and the MSs, which have the obligation of mutual cooperation in order to promote the necessary coherence in the process ${ }^{41}$ Communication on the food-chain- associated risks represents a key part of the EFSA's mandate. By communicating in an open and transparent manner on the basis of independent scientific output, the EFSA may contribute to public confidence in the food risk assessment process (Alemanno, 2008: 20).

Risk communication in the AS approval/renewal procedures has not always been effective. In some cases, most notably glyphosate, it has had negative impact on both consumers' confidence and the acceptability of risk management decisions (EC, 2018a: 41-43; EC, 2020a: 60). Shortcomings of the risk communication have been noted on two levels. On a general level, there are two key shortcomings: 1) occurrence of conflicting communications between the EU and MSs risk assessors, as well as the divergences between the EFSA, the Commission and MSs; and 2) the time gap between the EFSA's communication on its output in the risk assessment stage and risk management decisions, which can emphasise the perceived lack of clarity of the final decision-making process (EC, 2018a: 41-42). On the EFSA level, although communication was generally appraised as effective and of good quality, the shortcomings included: 1) lack of clarity, except for the informed public; 2) discrepancy in views on the appropriate communication targets; 3) media perception of excessive complexity; and 4) prevalence of English language (EC, 2018b: 86). Despite having taken certain steps to eliminate the shortcomings (EFSA, 2014a; EFSA 2017b), the EFSA still needs to improve communication in the MSs so that the public can better understand complex outputs (Ludden et al. 2018: 69-70).

To eliminate the shortcomings on both levels, various stakeholders have suggested the adoption of the overall strategy to coordinate risk communication throughout the entire process (EC, 2018a: 42-43,48). This solution is embedded in the

40 Art. 3(13), GFL 2002.

41 Art. 22(8), 40(3), GFL 2002. 
TR which envisages the adoption of the general plan for risk communication. The plan aims to establish an integrated risk communication framework for the risk assessors and risk managers to follow in both the EU and MSs. The Commission is tasked with adopting and updating the plan by means of implementing acts, and the EFSA has to be consulted during the pre-adoption process. ${ }^{42}$

\section{Conclusion}

In performing its role within the three aspects considered, the EFSA exerts significant impacts on the design, course and outcome of the AS approval/renewal procedure. First, by producing the de facto mandatory guidance documents, the EFSA provides the authoritative interpretation of legal requirements and defines the content of practical steps in the procedure. Second, publishing documents and deciding on confidentiality requests are important in the complex balancing between the public interest in access to information and the private interest in confidentiality of the commercially sensitive information, both of which are protected by EU law. Finally, preparing and submitting the conclusion contributes to the consistency of the procedure and serves as a basis for decision-making by the risk managers. The synergistic effect of these aspects produces a condition in which the EFSA, in spite of having no regulatory powers, has a decisive influence on whether an AS will be approved or banned, thus indirectly affecting the placement or withdrawal of a PPP from the €12 billion market.

The responses to the identified challenges related to all five elements of confidence in the EFSA did not cause radical changes of the current AS approval/ renewal system. Furthermore, the EFSA's role in it has become more important through the measures built into these responses, the most important of which are: 1) setting up the EFSA-managed online system for submitting applications and exchanging information in the procedure; 2) the EFSA's involvement in developing EU-wide quality criteria of the dossier and the DAR/RAR; 3) extending the EFSA's powers in deciding on confidentiality; 4) setting up the system of prior notification to the EFSA of all studies intended to be carried out in support of an application; 5) introducing a possibility for the EFSA to commission studies in cases of conflicting scientific findings related to the same AS; and 6) the EFSA's involvement in the preparation of the general plan for risk communication. Most of the measures are novelties introduced by the TR, and assessment of their effects will have to wait for the completion of AS approval/renewal procedures initiated after 27 March 2021.

42 Art. 8a-8c, GFL 2002, as amended by Art. 1(2), TR 2019. 


\section{References}

Abels, G., Kobusch, A., Träsch, J. (2016). Scientific Regulatory Cooperation within the EU: On the Relationship between EFSA and National Food Authorities. In Alemanno, A. and Gabbi, S. (eds.). Foundations of EU Food Law and Policy: Ten Years of the European Food Safety Authority (pp. 73-92). London, New York: Routledge.

Alemanno, A. (2008). The European Food Safety Authority at Five. European Food and Feed Law Review. 3 (1). 2-24.

Bozzini, E. (2018). Assessing criteria and capacity for reliable and harmonised 'hazard identification' of active substances. In: Dinu, A. and Karamfilova, E. Regulation (EC) 1107/2009 on the Placing of Plant Protection Products on the Market (pp. II-1-102). Brussels: European Parliamentary Research Service.

Bozzini, E. (2017). Pesticide Policy and Politics in the European Union: Regulatory Assessment, Implementation and Enforcement. Cham: Springer International Publishing.

Chatzopoulou, S., Leiva Eriksson, N., Eriksson, D. (2020). Improving Risk Assessment in the European Food Safety Authority: Lessons From the European Medicines Agency. Frontiers in Plant Science. 11. 349-359.

Christoforou, T. (2004). The Precautionary Principle, Risk Assessment, and the Comparative Role of Science in the European Community and the US Legal Systems. In: Vig, N. J. and Faure, M. G. (eds.). Green Giants? Environmental Policies of the United States and the European Union (pp. 17-51). Cambridge, Massachusetts, London: MIT Press.

Commission of the European Communities. (2006). Communication from the Commission to the Council, the European Parliament, the European Economic and Social Committee and the Committee of the Regions: A Thematic Strategy on the Sustainable Use of Pesticides. COM (2006) 372 final. Brussels. 12.7.2006.

European Commission. (2021). Administrative guidance on submission of dossiers and assessment reports for the peer-review of pesticide active substances and on the MRL application procedure. SANTE/10182/2021. 23 February 2021.

European Commission. (2020a). Commission Staff Working Document Accompanying the document Report from the Commission to the European Parliament and the Council: Evaluation of Regulation (EC) No 1107/2009 on the placing of plant protection products on the market and of Regulation (EC) No 396/2005 on maximum residue levels of pesticides. SWD (2020) 87 final. Brussels. 20.5.2020.

European Commission. (2020b). Communication from the Commission to the European Parliament, the European Council, the Council, the European Economic 
and Social Committee and the Committee of the Regions: A Farm to Fork Strategy for a fair, healthy and environmentally-friendly food system. COM (2020) 381 final. Brussels. 20.5.2020.

European Commission. (2020c). Report from the Commission to the European Parliament and the Council: Evaluation of Regulation (EC) No 1107/2009 on the placing of plant protection products on the market and of Regulation (EC) No 396/2005 on maximum residue levels of pesticides. COM (2020) 208 final. Brussels. 20.5.2020.

European Commission. (2019a). Communication from the Commission to the European Parliament, the European Council, the Council, the European Economic and Social Committee and the Committee of the Regions: The European Green Deal. COM (2019) 640 final. Brussels. 11.12.2019.

European Commission. (2019b). Implementation schedule: Administrative guidance on submission of dossiers and assessment reports for the peer-review of pesticide active substances. SANTE-10914-2019 rev.0. 22 March 2019.

European Commission. (2018a). Commission Staff Working Document: The REFIT Evaluation of the General Food Law (Regulation (EC) No 178/2002). SWD (2018) 38 final, part 1/2. Brussels. 15.1.2018.

European Commission. (2018b). Commission Staff Working Document: The REFIT Evaluation of the General Food Law (Regulation (EC) No 178/2002). SWD (2018) 38 final, part 2/2. Brussels. 15.1.2018.

European Commission. (2013). Commission Communication in the framework of the implementation of Commission Regulation (EU) No 283/2013 of 1 March 2013 setting out the data requirements for active substances, in accordance with Regulation (EC) No 1107/2009 of the European Parliament and of the Council concerning the placing of plant protection products on the market. OJ C 95. 3.4.2013. p. 1-20. European Court of Auditors. (2012). Management of Conflicts of Interest in Selected EU Agencies. Special Report No. 15. Luxembourg: European Court of Auditors.

European Food Safety Authority. (2021a). Administrative guidance on submission of dossiers and assessment reports for the peer-review of pesticide active substances and on the maximum residue level (MRL) application procedure. EFSA Journal: EFSA supporting publications. 18 (3). 1-77.

European Food Safety Authority. (2021b). Practical arrangements concerning transparency and confidentiality. 18 January 2021.

European Food Safety Authority. (2021c). Practical arrangements concerning confidentiality in accordance with Articles 7(3) and 16 of Regulation (EC) No 1107/2009. 11 Jan. 2021. 
European Food Safety Authority. (2021d). Practical arrangements on pre-submission phase and public consultations. 11 January 2021.

European Food Safety Authority. (2020). Programming document 2021-2023. 17 Dec. 2020.

European Food Safety Authority. (2019a). Administrative guidance on submission of dossiers and assessment reports for the peer-review of pesticide active substances. EFSA Journal: EFSA Supporting Publications. 16 (4). 1-49.

European Food Safety Authority. (2019b). Network on Pesticide Steering Meeting: Minutes of the 24 $4^{\text {th }}$ meeting held on 09-10 April 2019, Parma (Agreed on 06 May 2019).

European Food Safety Authority. (2018). EFSA rules on competing interest management. Parma. 1 July 2018.

European Food Safety Authority. (2017a). Action plan for improving the peer review process. EFSA Journal: EFSA Supporting Publications. 14 (2). 1-9.

European Food Safety Authority. (2017b). Risk Communication Guidelines When Food is Cooking up a Storm: Proven Recipes for Risk Communications. Parma.

European Food Safety Authority. (2017c). EFSA's policy on independence. Parma. 21 June 2017.

European Food Safety Authority. (2015). Network of Pesticide Steering: Minutes of the $17^{\text {th }}$ meeting held on 11-12.11.2014, Parma (Agreed on 10 February 2015).

European Food Safety Authority. (2014a). Risk Communication Guidelines When Food is Cooking up a Storm: Proven Recipes for Risk Communications. Parma.

European Food Safety Authority. (2014b). EFSA rules on Declarations of Interest. Parma. 31 July 2014.

European Food Safety Authority. (2011). Submission of scientific peer-reviewed open literature for the approval of pesticide active substances under Regulation (EC) No 1107/2009. EFSA Journal. 9 (2). 1-49.

Hardy, A., Fontier, H. (2011). Editorial: Conclusions on Pesticides. EFSA Journal. 9 (6). 1-4.

Hofmann, H. C. H. (2009). Composite decision making procedures in EU administrative law. In: Hofmann, H. C. H., Türk, A. H. (eds.). Legal Challenges in EU Administrative Law: Towards an Integrated Administration (pp. 136-167). Cheltenham, Northampton: Edward Elgar Publishing. 
Ludden, V., Godfrey, E., Kobilsky, A., Hahn, F., Jansen, L. (2018). The $3^{\text {rd }}$ Independent External Evaluation of EFSA 2011-2016: Final Report, Coffey International Development Ltd; Ramboll Management Consulting, Retrieved 11 Feb. 2021, from https://www.efsa.europa.eu/sites/default/files/3rd-Evaluation-of-EFSA_FinalReport100818.pdf.

Morvillo, M. (2020). Glyphosate Effect: Has the Glyphosate Controversy Affected the EU's Regulatory Epistemology? European Journal of Risk Regulation. 11 (3). 422-435.

Nganga, J., Bisonni, M., Christodoulou, M. (2018). Guidelines for submission and evaluation of applications for the approval of active substances in pesticides. Brussels: European Parliament - Policy Department for Economic, Scientific and Quality of Life Policies.

Ossege, C. (2015). Driven by Expertise and Insulation? The Autonomy of European Regulatory Agencies. Politics and Governance. 3 (1). 101-113.

Paskalev, V. (2020). The Clash of Scientific Assessors: What the Conflict over Glyphosate Carcinogenicity Tells Us about the Relationship between Law and Science. European Journal of Risk Regulation. 11 (3). 520-538.

Rimkutè, D. (2018). Mapping the practices of scientific (risk assessment) evaluation of active substances used in plant protection products. In Dinu, A., Karamfilova, E. Regulation (EC) 1107/2009 on the Placing of Plant Protection Products on the Market (pp. IV-1-130). Brussels: European Parliamentary Research Service.

Rimkutė, D. (2015). Explaining Differences in Scientific Expertise Use: The Politics of Pesticides. Politics and Governance. 3 (1). 114-127.

Robinson, C., Portier, C. J., Čavoški, A., Mesnage, R., Roger, A., Clausing, P., Whaley, P., Muilerman, H., Lyssimachou, A. (2020). Achieving a High Level of Protection from Pesticides in Europe: Problems with the Current Risk Assessment Procedure and Solutions. European Journal of Risk Regulation. 11 (3). 450-480.

Röttger-Wirtz, S. (2020a). Case C-616/17 Blaise and Others: The precautionary principle and its role in judicial review - Glyphosate and the regulatory framework for pesticides. Maastricht Journal of European and Comparative Law. 27 (4). 529-542.

Röttger-Wirtz, S. (2020b). WP2 D.2.3 Glyphosate case study. Retrieved 22 January 2021, from https://recipes-project.eu/sites/default/files/2020-10/_CS6_Glyphosate.pdf. 
Smith, A., Terry, S., Detken, D. (2012). 10 Years of the European Food Safety Authority (EFSA) and the EU Food Safety System. European Food and Feed Law Review. 7 (3). 111-116.

Vogel, D. (2012). The Politics of Precaution: Regulating Health, Safety, and Environmental Risks in Europe and the United States. Princeton, Oxford: Princeton University Press.

Vos, E., Athanasiadou, N., Dohmen, L. (2020). EU Agencies and Conflicts of Interests. Brussels: European Parliament -Policy Department for Citizens' Rights and Constitutional Affairs.

Legal acts

Commission Implementing Regulation (EU) No 844/2012 of 18 September 2012 setting out the provisions necessary for the implementation of the renewal procedure for active substances, as provided for in Regulation (EC) No 1107/2009 of the European Parliament and of the Council concerning the placing of plant protection products on the market, OJ L 252, 19.9.2012, p. 26-32.

Commission Implementing Regulation (EU) 2020/1740 of 20 November 2020 setting out the provisions necessary for the implementation of the renewal procedure for active substances, as provided for in Regulation (EC) No 1107/2009 of the European Parliament and of the Council, and repealing Commission Implementing Regulation (EU) No 844/2012, C/2020/7982, OJ L 392, 23.11.2020, p. 20-31.

Commission Regulation (EU) No 283/2013 of 1 March 2013 setting out the data requirements for active substances, in accordance with Regulation (EC) No 1107/2009 of the European Parliament and of the Council concerning the placing of plant protection products on the market, OJ L 93, 3.4.2013, p. 1-84.

Council Directive 91/414/EEC of 15 July 1991 concerning the placing of plant protection products on the market, OJ L 230, 19.8.1991, p. 1-32.

Regulation (EC) No 178/2002 of the European Parliament and of the Council of 28 January 2002 laying down the general principles and requirements of food law, establishing the European Food Safety Authority and laying down procedures in matters of food safety, OJ L 31, 1.2.2002, p. 1-24.

Regulation (EC) No 1107/2009 of the European Parliament and of the Council of 21 October 2009 concerning the placing of plant protection products on the market and repealing Council Directives 79/117/EEC and 91/414/EEC, OJ L 309, 24.11.2009, p. 1-50. 
Regulation (EU) 2019/1381 of the European Parliament and of the Council of 20 June 2019 on the transparency and sustainability of the EU risk assessment in the food chain and amending Regulations (EC) No 178/2002, (EC) No 1829/2003, (EC) No 1831/2003, (EC) No 2065/2003, (EC) No 1935/2004, (EC) No 1331/2008, (EC) No 1107/2009, (EU) 2015/2283 and Directive 2001/18/EC, PE/41/2019/ REV/1, OJ L 231, 6.9.2019, p. 1-28.

\section{Слађана Младеновић,}

истраживач сарадник,

Институт за политичке студије, Београд

\section{УЛОГА ЕВРОПСКЕ АГЕНЦИЈЕ ЗА БЕЗБЕДНОСТ ХРАНЕ У ПОСТУПЦИМА ОДОБРЕЊА И ОБНОВЕ ОДОБРЕЊА АКТИВНЕ СУПСТАНЦЕ У ОКВИРУ ПОЛИТИКЕ ПЕСТИЦИДА ЕВРОПСКЕ УНИЈЕ}

\section{Резиме}

Европска агенција за безбедност хране у оквиру три кључна аспекта својеулоге остварује снажан утицај на обликовање, ток и исход поступака одобрења и обнове одобрења активне супстанце. Прво, доношењем de facto обавезујућих смерница, агенција ауторитативно тумачи прописе и одређује садржај прощесних корака. Друго, објављивање докумената и одлучивање о захтевима за поверљивост значајни су у сложеном балансирању између два интереса које штити право ЕУ - јавног интереса за приступ информацијама и приватних интереса за поверљивост осетљивих комерцијалних информација. Коначно, процес израде закључка доприноси уједначеној примени поступака и служи као основа за одлучивање у фази управљања ризиком. Синергетски ефекат ових аспеката доводи до стања у коме агенција, иако нема регулаторне надлежности, има пресудан утицај на то да ли ће активна супстанца бити одобрена или забрањена, чиме посредно утиче на то који ће производ за заштиту биља бити стављен на тржиште вредно 12 милијарди евра, или повучен са њега.

Иако је поверење у агенцију, у начелу, на високом нивоу, уочене су две врсте изазова у вези са свих пет елемената поверења. Прва врста се односи на изазове који проистичу из поставки самог система и ограничених капацитета држава чланица и агенције да га примене. Одговори на њих обухватају низ мера за побољшање кадровских и материјалних капацитета агенције, као и процесне измене у циљу поједностављивања и убрзања поступака. Друга врста је повезана са перцепцијом да индустрија има превелики утищај на 
обликовање и исход поступака. Одговор на то подразумева успостављање система који би могао делотворније да контролише спровођење студија које индустрија користи у поступку, као и да решава проблеме у случајевима када постоје супротстављени налази различитих научних студија у вези са истом активном супстанцом. Мере уграђене у ове одговоре, а посебно оне прописане Регулативом о транспарентности, додатно оснажују улогу агенције у поступцима.

Кључне речи: Децентрализоване агенције ЕУ, Европска агенција за безбедност хране, политика пестицида ЕУ, одобрење активне супстанце, обнова одобрења активне супстанце, Опште законодавство у области хране, Регулатива о производима за заштиту биља, Регулатива о транспарентности. 